Original Research Paper

\title{
Pengembangan Potensi Usaha Buah-buahan Menjadi Aneka Makanan dan Minuman Segar dan Sehat Sebagai Upaya Peningkatan Nilai Ekonomi Masyarakat Lingkungan Pasar Buah Bertais di Era New Normal
} \author{
Karisma Wijayanti ${ }^{3}$ \\ ${ }^{I}$ Fakultas Matematika dan Ilmu Pengetahuan Alam, Universitas Mataram, Mataram, Indonesia \\ ${ }^{2}$ Fakultas Ekonomi, Universitas Mataram, Mataram, Indonesia \\ ${ }^{3}$ Fakultas Kguruan dan Ilmu Pendidikan, Universitas Mataram, Mataram, Indonesia
}

Ahmad Jupri ${ }^{1}$, Eka S. Prasedya ${ }^{1}$, Heri Susanto ${ }^{2}$, Ni Komang Rai $\mathbf{P}^{2}$, Ni Komang Sri $\mathbf{J}^{2}$, Pujangga Sastra $\mathrm{K}^{3}$

DOI: https://doi.org/10.29303/jpmpi.v4i2.694

Sitasi: Jupri, A., Prasedya, E. S., Susanto, H.., Rai P. N., Sri J, N. K., Sastra K, P. S., \& Wijayati, K. (2021). Pengembangan Potensi Usaha Buah-buahan Menjadi Aneka Makanan dan Minuman Segar dan Sehat Sebagai Upaya Peningkatan Nilai Ekonomi Masyarakat Lingkungan Pasar Buah Bertais di Era New Normal. Jurnal Pengabdian Magister Pendidikan IPA, 4(1)

\author{
Article history \\ Received: 03 Januari 2021 \\ Revised: 08 Maret 2021 \\ Accepted: 29 Maret 2021 \\ *Corresponding Author: \\ Ahmad Jupri, Fakultas \\ Matematika dan Ilmu \\ Pengetahuan Alam Universitas \\ Mataram, Mataram, Indonesia; \\ Email: juprizikril@gmail.com
}

\begin{abstract}
Kelurahan Bertais merupakan daerah perdagangan besar dengan berbagai macam komoditas, salah satunya yaitu buah-buahan segar. Berada di lingkungan pasar buah yang berpenduduk sebagian besar berprofesi sebagai pedagang buah dan lingkungan pasar merupakan lingkungan yang relatif panas, membuat masyarakat sekitar menjadi lebih konsumtif dengan makanan atau minuman penyegar. Tujuan pembuatan produk ini adalah untuk membuat buah-buahan segar menjadi produk yang lebih inovatif serta lebih menarik untuk dikonsumsi, karena berada di lingkungan pasar buah memungkinkan masyarakat akan merasa bosan mengonsumsi buah segar atau buah yang tidak diolah. Serta akan menambah daya tarik pengunjung pasar untuk mengonsumsi buah dalam bentuk sebuah produk penyegar. Salah satu ide yang dikembangkan adalah membuat minuman segar dan makanan ringan dengan harga yang relatif murah sehingga dapat dijangkau oleh masyarakat, mulai dari anak anak sampai orang dewasa. Pemasaran produk ini akan dilakukan secara offline dan online. Pemasaran secara offline dilakukan dengan mendirikan stand kecil-kecilan di lingkungan pasar, dan pemasaran secara online dilakukan dengan memposting produk di media sosial dan membuat fasilitas delivery atau pesan antar.
\end{abstract}

Keywords: Komoditas; Pasar buah; Inovasi.

\section{Pendahuluan}

Kelurahan Bertais merupakan salah satu sektor perdagangan terbesar di pulau Lombok, Nusa Tenggara Barat. Letak geografis wilayah keluarhan Bertais terletak dibagian Timur Kota Mataram, kurang lebih $5 \mathrm{~km}$ dengan luas wilayah kelurahan Bertais adalah 238,572 Ha sehingga merupakan daratan yang cukup baik untuk perumahan, permukiman, dan perdagangan dngan batas-batas wilayah sebagai berikut: batas sebelah utara, batas sebelah selatan, batas sebelah barat, dan batas sebelah timur adalah Kelurahan Selagalas, Kelurahan Desa Mekar Sari Lombok Barat, Kelurahan Mandalika, Kelurahan Desa Gerimax Indah Lombok Barat dengan kondisi geografis batas kelurahan Bertais arah utara-selatan $8 \quad 34$ $40 \mathrm{~S}$ barat-timur $1160720 \mathrm{E}$, sedangkan luas wilayah seperti di atas telah diatur suatu tata ruang 
yang terdiri dari: (1) Lahan pertanian : 136,29 $\mathrm{Ha}$ (2) Pekarangan: 18,00 Ha (3) Pemukiman: 48,131 Ha (4) Kuburan: 3,03 Ha (5) Perkantoran: 2,15 Ha (6) Fasilitas Umum: 26,39 Ha (7) Perkebunan: 6,03 Ha. Karena letaknya yang sangat strategis maka cukup membantu masyarakat dalam melaksanakan segala aktifitasnya, apalagi dengan dibukanya jalan baru, J1. Imam Syafi'i maka akses ke berbagai tempat semakin mudah dijangkau dengan jarak antara: pemerintahan Kecamatan: kurang lebih $0,5 \mathrm{~km}$, pemerintahan kota: kurang lebih $3 \mathrm{~km}$, pemerintah provinsi: kurang lebih $3 \mathrm{~km}$, pusat perbelanjaan: kurang lebih $0,70 \mathrm{~km}$.

Masyarakat di kelurahan Bertais sendiri sebagian besar berprofesi sebagai pedagang. Perdagangan di pasar bertais terbagi menjadi banyak komoditas, diantaranya yaitu bahan pokok/sembako, perlengkapan rumah tangga dan buah- buahan. Dari beberapa komoditas yang ada kami mengambil peluang pada komoditas buahbuahan. Buah yang dipasarkan di pasar bertais merupakan buah-buahan segar yang dijual secara grosir atau pembelian dalam jumlah besar.

Berada di lingkungan pasar buah yang hanya terdapa tbuah-buahan segar serta lingkungan pasar yang cenderung panas membuat kami berfikir untuk memanfaatkan usahakecil-kecilan yaitu pemanfaatan buah-buahan segar di tempat tersebut menjadi makanan dan minuman kekinian. Masyarakat sekitar yang sebagian besar menjadi pedagang buah dan terlalu sibuk dengan kegiatannya sebagai pedagang buah grosir, terkadang membuatnya kurang memikirkan atau bahkan mungkin tidak sempat mengolah buahbuahan tersebut menjadi makanan siap saji yang lebih menarik dan lebih beraneka rasa sehingga menimbulkan kebosanan untuk mengonsumsi buahbuahan. Lingkungan pasar yang cenderung panas membuat kami memikirkan ide usaha produk penyegar. Selain untuk warga sekitar, produk ini juga akan dikenalkan kepada pedagang-pedagang yang datang untuk berbelanja. Namun dengan sistem pemasaran tambahan kami memanfaatkan media sosial dalam promosi produk ini. Jadi dapat juga dijangkau oleh masyarakat di luar pasar atau masyarakat yang tidak bisa datang ke pasar Bertais.

Produk yang akan kami buat merupakan produk minuman dan makanan berbahan dasar buah segar. Karena memanfaatkan lingkungan pasar buah, harga buah yang mana menjadi sebagai bahan dasar produk kami akan di dapatkan dengan murah dan terjamin kesegarannya. Terlebih lagi, usaha makanan dan minuman berbahan dasar buah segar yang akan kami kembangkan ini juga didampingi oleh usaha tokobuah segar milik salah satu anggota kelompok kami, dan kami memiliki tujuan agar para pedagang buah yang lain dapat menyadari begitu banyak peluang usaha lain selain menjual buah secara grosis yang bahkan dapat mengembangkan usahanya tersebut menjadi usaha makanan dan minuman siap saji sehingga para pedagang pun mendapatkan pemasukan yang lain selain dari usaha tetapnya tersebut.

Buah-buahan yang ada di pasar Bertais didapatkan dari berbagai wilayah. Buah-buah impor seperti apel Fuji, buah pir, anggur merah,anggur hijau,anggur hitam didatangkan dari Surabaya. Buah- buahan lokal seperti manggis, Sirsak, mangga,rambutan merupakan buah hasil petani lokal Lombok. Buah-buahan seperti salak, buah naga, jambu kristal, jeruk bali merupakan buah yang didatangkan dari Bali.

\section{Metode}

1. Waktu dan Tempat

Program KKN Era New Normal 2021 ini dilakukan di lingkungan pasar buah Bertais, Kelurahan Bertais Mandalika Sandubaya, Mataram. Kegiatan ini dimulai pada 19 Januari 2021 s/d 25 Februari 2021.

\section{Alat dan Bahan}

Bahan yang digunakan pada program ini adalah : untuk aneka minuman yaitu, buah naga, buah jeruk, buah nanas dan Yakult, gula, dan es batu. Sedangkan untuk rujak bahan-bahannya adalah; buah rambutan, jambu kristal, cabai bubuk, gula, garam,

Alat yang digunakan yaitu blender, ice box, gelas, plastic, mika, sedotan, dan pisau. Untuk menjaga kehigenisan produk pada masa pandemi Covid-19 ini, kami selalu menggunakan masker, dan sarung tangan.

\section{Prosedur Pembuatan}

Ice Y-fruits: (1) kupas buah lalu potong,

(2) blender bersama es batu, (3) masukkan kedalam gelas plastic, (4) tuangkan Yakult, (5) siap dihidangkan.

Rujak Single: (1) kupas buah, (2) bersihkan dengan air mengalir, (3) tambahkan cabai bubuk 
dan gula halus, (4) campurkan/aduk sampai buah merata dengan bumbu, (5) masukkan ke dalam mika, (6) siap dihidangkan.

\section{Kegiatan}

Bentuk kegiatan dalam program ini mencoba mengembangkan usaha buah grosiran menjadi olahan siap saji yang tentunya sehat. Mengingat pada Era New Normal ini, pentingnya mematuhi protokol yang ada, juga tentu menjaga imun tubuh tetap terpenuhi. Berangkat dari pemikiran itu, pemamfaatan buah-buahan segar di area pasar buah bertais sangat memungkinkan dan mendukung produk kami tercipta. (1) Melakukan survei harga alat dan bahan minuman, (2) Pembelian alat dan bahan, (3) mempersiapkan alat dan bahan, (4) pembuatan produk, (5) melakukan promosi dan penjualan produk dengan memanfaatkan sosial media.

\section{Hasil dan Pembahasan}

Pengembangan potensi usaha buah- buahan segar menjadi makanan dan minuman sehat ini bertujuan, agar para pedagang di pasar bertais dapat bersaing dibidang pemasaran yang sudah termasuk modern, bahwasanya apabila para pemilik toko dapat juga termotivasi untuk mampu bersaing dalam pemasaran berbasis teknologi dan kekinian. Juga memberikan motivasi atau langkah awal yang bagus dalam membangun usaha kecil bagi para kurir yang berada di area pasar buah Bertais. Memperkenalkan minuman kekinian kepada masyarakat setempat ini juga bertujuan untuk membangun motivasi masyarakat setempat atau lebih tepatnya remaja setempat agar termotivasi untuk mengembangkan kreatifitas yang mereka miliki dalam membuka usaha baru sehingga dapat mengurangi jumlah pengangguran yang ada di desa, dan juga dapat memunculkan calon pengusahapengusaha baru.

Selain itu, ide jualan ini juga dapat menjadi contoh untuk usaha kecil dengan budget minimal namun dengan keuntungan yang lumayan, mengingat di komplek pasar buah grosir cenderung harga buah lebih murah namun dalam bentuk olahan dapat di jual dengan harga pasaran normal seperti harga-harga produk minuman yang hampir serupa sehingga keuntungan yang dapat di raup lumayan banyak. Masyarakat sekitar tempat KKN juga terlihat antusias dengan produk yang kami buat, beberapa dari mereka menjadi pelanggan tetap karena merasa puas dengan produk yang kami buat.

Selain program kerja utama, kelompok KKN kami juga melakukan program kerja tambahan yaitu melakukan promosi serta mamasarkan produk di luar lingkungan tempat $\mathrm{KKN}$, yaitu dengan mendirikan stand jualan saat CFD hari minggu pagi di jalan Udayana. Tujuan kami mempromosikannya yaitu untuk mengenalkan produk pada masyarakat luas serta mengenalkan ide untuk mengonsumsi olahan buah segar yang membantu menjaga kesehatan.

Program kerja tambahan lain yang berhubungan dengan masyarakat tidak kami lakukan mengingat lingkungan $\mathrm{KKN}$ merupakan lingkungan masyarakat pendatang dari banyak penjuru daerah, dikarenakan masa pandemic alangkah baiknya untuk mengurangi sosialisasi seta jaga jarak dengan orang banyak.

Hasil penjualan dari makanan dan minuman selama 45 hari terjual kurang lebih sebanyak 200 gelas Ice Y-Fruits, yakni dengan rincian dalam sehari dapat menghabiskan $1 / 2 \mathrm{~kg}$ buah jeruk, 2 buah nanas, 3 buah naga, dan 10 bungkus yakult. Sedangkan untuk penjualan rujak single dalam sehari yakni dengan rincian menghabiskan kurang lebih 1 kilo buah jambu Kristal, 1 buah nanas, dan kurang lebih $1 / 2 \mathrm{~kg}$ buah rambutan. Sehingga total penjualan dalam sehari mencapai kurang lebih Rp. 200.000 sampai Rp 300.000. Dan total penjualan selama KKN kurang lebih mencapai Rp. 2.500.000.

Kami berharap dengan adanya inovasi baru yang kami lakukan selama KKN dapat menjadi sebuah peluang baru bagi masyarakat lain untuk menggelutinya dan mencobanya, dan seusai KKN nantinya akan ada masyarakat yang berkeinginan untuk meneruskan ide jualan tersebut.

\section{Kesimpulan}

Pengembangan potensi usaha buah- buahan segar menjadi makanan dan minuman sehat ini bertujuan, agar para pedagang di pasar bertais dapat bersaing dibidang pemasaran yang sudah termasuk modern, bahwasanya apabila para pemilik toko dapat juga termotivasi untuk mampu bersaing dalam pemasaran berbasis teknologi dan kekinian. ide jualan ini juga dapat menjadi contoh untuk usaha kecil dengan budget minimal namun dengan keuntungan yang lumayan, inovasi baru yang kami lakukan selama KKN dapat menjadi sebuah 
peluang baru bagi masyarakat lain untuk menggelutinya dan mencobanya, dan seusai $\mathrm{KKN}$ nantinya akan ada masyarakat yang berkeinginan untuk meneruskan ide jualan tersebut.

\section{Ucapan Terima Kasih}

Ucapan terima kasih kami sampaikan kepada Dosen pembimbing KKN Bapak Dr. Drs. Ahmad Jupri, M.Eng. selaku dosen pembimbing lapangan, dan seluruh masyarakat yang ada di Desa Bertais serta semua pihak yang telah membantu selama kegiatan KKN berlangsung.

\section{Daftar Pustaka}

https://www.google.co.id/url?sa=t\&source=w eb\&rct=j\&url=http://www.sipppid.mataramkota.go.id/download-dip614\&ved=2ahUKEwjzsLnYzaLvAhVRX3 $0 \mathrm{~K}$

$\mathrm{Hd} 4 \mathrm{wCnIQFjACegQICBAD \& usg=AOvVa}$ w 2P_vyoBk_jVWtix8nHxiTm

https://www.google.co.id/url?sa=t\&source $=\mathrm{w}$ eb\&rct=j\&url=https://www.alodokter.com/ ma nfaat-buah-untuk-kesehatan-yang-perluanda-

ketahui\&ved=2ahUKEwjtsPWFzqLvAhUR VH0KHX98D kQFjABegQIBBAF\&usg=AOvVaw3GUC 1d BJJrsKZV7t-qns9n

https://www.google.co.id/url?sa=t\&source=w eb\&rct=j\&url=https://www.popbela.com/be au ty/health/amp/shavira-annisaputri/manfaatyakult\&ved=2ahUKEwiv1aSxzqLvAhWM fn

0KHSf1AB0QFjASegQIJxAC\&usg=AOv $\mathrm{Va}$ w2PSD2QVfsIO4NpJHFdTwEb\&ampcf=1 